\title{
APPROACH FOR SUSTAINABLE PROCESSES FOR THE BUILT ENVIRONMENT IN TRIPLE HELIX COOPERATION - THE CASE OF STORSJÖ STRAND IN ÖSTERSUND
}

\author{
Jonas Jonasson \\ Itai Danielski \\ Lars Åke Mikaelsson \\ Morgan Fröling \\ Department of Ecotechnology and Sustainable Building, \\ Mid Sweden University, Sweden
}

\begin{abstract}
The built environment is an important component for a sustainable society. Choices made today will affect society during decades to come, both regarding performance of buildings and in affecting what is possible choices regarding mobility, energy, waste handling and human well being in general. There have been several projects in Sweden and around the world aiming at better sustainability performance of new built areas. A strong experience from earlier projects is that it is not that easy to actually achieve high ambitions set up at project initiation; the most common example in this direction that requirements on energy efficiency are not achieved when measuring in actual use of the final building.
\end{abstract}

The project Storsjö Strand, a new township in Östersund in an earlier industrialized area, has aimed to work around identified earlier problems, using a strong interactivity and a triple helix process with the municipality, developers, and the university. The role of the university is to through an action research approach both be involved in the process to help guide it and to document and evaluate the process, with the research goal to contribute to and develop sustainable building processes for Sweden and elsewhere.

The Storsjö Strand project is presently an ongoing project. This paper describes the approach taken and how it is a development of earlier approaches for sustainable building processes and also evaluates early experiences of the triple helix process.

\section{KEYWORDS}

Sustainable building; Building processes; Integrated Planning, Energy efficiency. 


\section{INTRODUCTION}

The municipality of Östersund is presently developing a new township called Storsjö Strand close to the town centre by the lakefront of the lake Storsjön. The ambition is that the new area should be a good example of more sustainable building engineering and societal planning. The location is attractive, in past times for industrial purposes, in present time for housing. The area that has been used by the Swedish National Railway for shunting and storing, and by some smaller industries including a brewery and a building store, is now being planned for around 500 dwellings, in a mixed township with stores, offices, walking paths and park areas [1].

The planning and infrastructure that we live in today was planned decades ago, and we will be living in areas where the planning is done today for decades to come. This is apparent in the Storsjö Strand case. The area's, and to some extent society's, history complicates the desired development because of the industrial background and the areas close proximity to the railroad. The lakefront location also imposes some challenges especially as Storsjön is the source of the city's drinking water. Building a sustainable society demands a long-term perspective, an understanding of the fact that societies needs and values may change over time, and willingness to adapt to the locations preconditions.

Construction of buildings is intimately connected with some sort of need, and a developer is probably more concerned with what should be built to satisfy his/her needs, than how it is built. The developer's role in the Swedish building sector has changed over the past 70 years from being the owner, real estate developer, construction client, project developer, and contractor all in one towards being just the project owner, not least in the public sector [2]. This shift has resulted in a weakening of the developer's building and ordering competence. Hence the developer or owner today generally has less influence on the technical design of a project A residential building in Sweden is mainly developed by and on the initiative of a few large contracting companies that build to sell. This means that there is a risk that production economic factors can be prioritized higher than the future owners' needs and interests. [3].

Building is a complex process, with many actors involved, even without thinking of sustainability. Sustainable building spans over many areas of competence, and adds even more complexity to a building project. New building techniques and new materials might need to be introduced, and specialists from other professions than usual also need to be involved in the process. This increases the number of unknowns and thus potential risk for the contractor (or developer depending on the contract situation of the project). To control the process from start to finish means increased possibilities to avoid or at least reduce risk, and the large contracting companies have in recent years launched sustainability programs, to achieve a more sustainable production in a manner suitable for their own production process.

A strong experience from earlier projects is that it is not easy to actually achieve high ambitions set up at project initiation. The most common example in this direction is requirements on energy efficiency not achieved when measuring the actual energyuse of the final building [4].

A project owner/developer with sustainability goals and demands must communicate them to all actors in the process, this communication of the goals is best performed in a dialog [5]. 


\section{PURPOSE AND METHODS}

The overarching purpose of this study is to test and evaluate a refined model of Integrated Planning for Sustainable Building Production, see Figure 1 [5] .The model emulates Deming's (1986) four quality cycle stages of Plan, Do, Study and Act. Sustainable building production here means that there is focus on leadership, quality, environmental- and work environment- management in a building construction process.

One problem with the building process is to overcome the critical boarderline between the different stages in process (projecting - production planning - building). The concept Integrated Planning includes a model to handle this with respect to keep the visions and intentions from earlier stages and involve actors in the following stages [5].

The entire study is mainly based on an action research approach with the aim that stages and activities in the study will de linked together in an ongoing process. The original Integrated Planning (IP) model [5] had the focus on the production process but in this study the model is applied already in the programming and projecting phases. That means that all actors in the building process are included in the joint planning group. Action research means that also the researchers are participating in the planning group in the same time as they are mapping and studying the process.

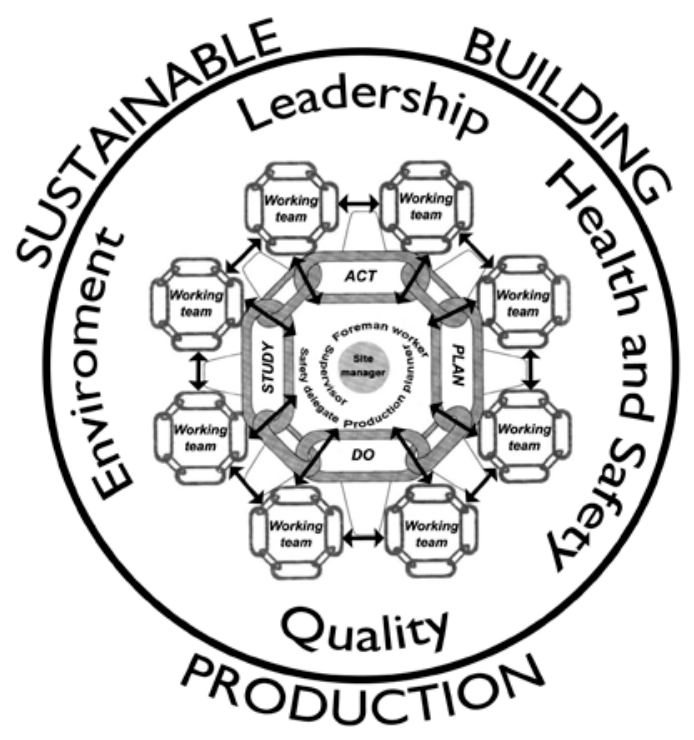

Figure 1. Integrated Planning for Sustainable Building Production [5]. 


\section{RESULTS AND DISCUSSION}

There have been several projects in Sweden and around the world aiming at better sustainability performance of new built areas. Some earlier projects with sustainable building profile have also been made in Östersund, e.g. The Remonthagen project and the public housing company Östersundshem's project Fagerskrapan, a 16 story building with 56 dwellings in southern parts of Östersund The Remonthagen project started as a citizen's proposal that an Ecological village should be built at Remonthagen in the eastern part of Östersund. The conclusion from both these projects is that is hard to actually achieve high sustainability ambitions set up at project initiation. Energy efficiency seems to be the parameter easiest to grasp, even if energy goals are not always reached either[4]. One explanation could be economy; it makes sense to save energy and therefore money, during a buildings use phase. Another explanation could be that to build more energy efficient is a rather easy adaptation of current building methods. In order to make also other sustainability goals "survive" through the building process all the way into the finished house, the goals and demands must be well defined, as far as possible measureable, and concrete. The often occurring mismatch between calculated values and values measured in the final building regarding energy use mentioned earlier [4] indicates that measurability is vital to verify if a goal is met or not.

To communicate the municipality's goals and demands, and to define and specify "sustainable building" in the Storsjö Strand project, The Storsjö Strand sustainability program was created. This document is the overall policy document for sustainability issues of the project, and also acts as a code of conduct for the planning of Storsjö Strand project[6]. The program is based on:

- the national environmental goals of Sweden

- regional environmental goals of Jämtland County

- the Östersund municipality environmental goals,

- BREEAM communities 2012, and

- Miljöbyggnad 2.1 level Gold for new buildings.

The program has been developed by a policy group consisting of representatives from the municipality, a project manager, and four external experts on sustainable city development. The document is not a static protocol, but is constantly evaluated and discussed in meetings between the developers, the municipality and Mid Sweden University. The developers were invited at an early stage of the process to be able to be a part in the overall and detailed planning of the area, and to help developing the goals and sustainability aspects of the project. The sustainability program will be updated at every new stage of the project, using feedback from the earlier stages.

It will be necessary to measure the performance of many of the different sustainability program goals, in the end product, i.e. the finished buildings. The process of evaluating and developing methods for measuring is currently taking place in cooperation between developers, the public energy company Jämtkraft, and the university.

Since the program and projecting stages are not ready yet it is too early to judge the outcome from the study. However there are some indications that some of the sustainability factors can be better fulfilled according to the ambitions and goals of the Storsjö Strand project than what has sometimes been the experience in other projects. One interesting matter is that one of the 
contractors has decided to use construction based on timber frame. This could be seen as an outcome from the early discussions in the planning group where the researchers have been arguing for wood as a comparable sustainable material.

\section{CONCLUSIONS}

The project Storsjö Strand, a new township in Östersund in an earlier industrialized area, has the aim to be a good example of more sustainable building engineering and planning.

One part of reaching the goals for the project is using a strong interactivity and a triple helix process with the municipality, developers, and the university. Evaluation of the early process toward integrated planning theory indicates that the implementing process has worked well so far. Mid Sweden University will continue to study the project and process through participatory action research.

\section{ACKNOWLEDGMENT}

We gratefully acknowledge the financial support of the European Union Regional Development Fund

\section{REFERENCES}

[1] Östersunds kommun, 2009. Översiktsplan Storsjö Strand (General Planning Storsjö Strand). Samhällsbyggnad Östersunds kommun, Östersund, Sweden (in Swedish) [2] Delsenius, S. E., 2009 Byggherren och Byggherrerollens utveckling i svenskt bostadsbyggande, åren 1945 - 2005 (The evolution of the Swedish Developer and Construction Client in housing development, 1945-2005). Lic thesis, Department of Real Estate and Construction Managment, Royal Institute of Technology (KTH), Stockholm, Sweden (in Swedish)

[3] Byggkommissionen, 2002. Skärpning gubbar! Om konkurrensen, kvaliteten, kostnaderna och kompetensen i byggsektorn. SOU_2002:115. Socialdepartementet, Stockholm, Sweden (in Swedish)

[4] Danielski, I., 2012. Large variations in specific final energy use in Swedish apartment buildings: Causes and solutions. Energy and Buildings, doi:101016/j.enbuild.2012.02.015 [5] Mikaelsson L-Å, Larsson, J., 2014. Integrated Planning for Sustainable Building Production - an evolution over three decades. Accepted for publication in Journal of Civil Engineering and Management.

[6] Engberg, J., Nordberg M., 2013. Hållbarhetsprogram Storsjö Strand (Sustainability Program Storsjö Strand), Available at: http://www.ostersund.se/download/18.6c1eb18a13ec7d9b5b82c6e/1370441663438/H\%C3 \%A5llbarhetsprogram_storsj\%C3\%B6strand+2013-05-20.pdf . Acessed 15 october, 2015. 